\title{
Natural Salicylates and Their Roles in Human Health
}

\author{
Fatema Yeasmin and Hyong Woo Choi * \\ Department of Plant Medicals, Andong National University, Andong 36729, Korea; fatema.setudu@gmail.com \\ * Correspondence: hwchoi@anu.ac.kr
}

Received: 31 October 2020; Accepted: 26 November 2020; Published: 28 November 2020

\begin{abstract}
Salicylic acid (SA) is a plant hormone which plays a crucial role in the plant defense against various pathogens and abiotic stresses. Increasing reports suggest that this phenolic compound and its derivatives, collectively termed salicylates, not only regulate plant defense but also have beneficial effects on human health. Both natural and synthetic salicylates are known to have multiple targets in humans, thereby exhibiting various appreciating pharmacological roles, including anti-inflammatory, anticancer, neuroprotective, antidiabetic effects, and so on. The role of some salicylates, such as acetylsalicylic acid (aspirin), 5-aminosalicylic acid (mesalazine), and amorfrutins in human diseases has been well studied in vitro. However, their clinical significance in different diseases is largely unknown. Based on recent studies, five natural salicylates, including amorfrutin, ginkgolic acid, grifolic acid, tetrahydrocannabinolic acid, and cannabidiolic acid, showed potential roles in different challenging human diseases. This review summarizes together some of the recent information on multitarget regulatory activities of these natural salicylates and their pharmacological roles in human health.
\end{abstract}

Keywords: salicylates; pharmacological role; amorfrutin; ginkgolic acid; grifolic acid; tetrahydrocannabinolic acid; cannabidiolic acid

\section{Introduction}

Traditionally, plants with a high level of salicylates have been used therapeutically throughout the world. Nowadays, salicylates containing plants are used as substitutes for nonsteroidal anti-inflammatory drugs (NSAIDs). In the fourth century B.C., the father of medicine Hippocrates reportedly prescribed extracts of willow leaves or barks to reduce fever and pain during childbirth [1]. In 1828, the active ingredient salicin (SA derivative) of the willow tree was isolated which is known to be converted to SA upon ingestion. Another natural salicylate methyl salicylate (MeSA), which is found in wintergreen, birch tree, mango, meadowsweet, guelder-rose, is used as analgesic medicine (for joint and muscular pain) and fragrance [2-6]. In the middle of the nineteenth century, an intense increase in the medicinal use of SA occurred due to the identification of salicin from willow plants as an anti-inflammatory compound. For growing demand, synthetic SA production was begun commercially in 1874. The most commonly used and recognized salicylate is aspirin (acetyl SA), which was first synthesized by Bayer in 1897. SA had some negative side effects, such as stomach irritation and bleeding, thus it was replaced with aspirin with fewer side effects [7]. Recent studies suggest that Aspirin not only reduces fever, inflammation, and pain but also reduces the risk of stroke, heart attack, and some type of cancers [8-10]. The mechanism of analgesia occurred by aspirin involves the suppression of prostaglandin synthesis by irreversible inhibition of the cyclooxygenases COX1 and COX2 [11]. Aspirin is also known to target other human proteins, such as nuclear factor-kappaB (NF- $\mathrm{kB}$ ), cathepsin A (CTSA), ribosomal S6 kinase 2 (RSK2), and cyclin-dependent kinase 2 (CDK2) [12-14]. Both natural and synthetic salicylates have beneficial effects for the treatments of different diseases as salicylates can target different human proteins (Table 1). For example, 5-aminosalicylic acid targets arachidonate 
5-lipoxygenase (ALOX5) and glyceraldehyde 3-phosphate dehydrogenase (GAPDH) protein [15,16]; Sulfasalazine targets ALOX5 and tumor necrosis factor (TNF $\alpha$ ) protein $[15,17]$; Sodium salicylate targets COX2 and NF-kB [18]; GAPDH and High mobility group box 1 (HMGB1) both are targeted by acetyl 3-aminoethyl salicylic acid [16,19]. Thus, salicylates play an important role as a pharmacological agent in human health.

Table 1. Salicylates with their structures and targeted protein.

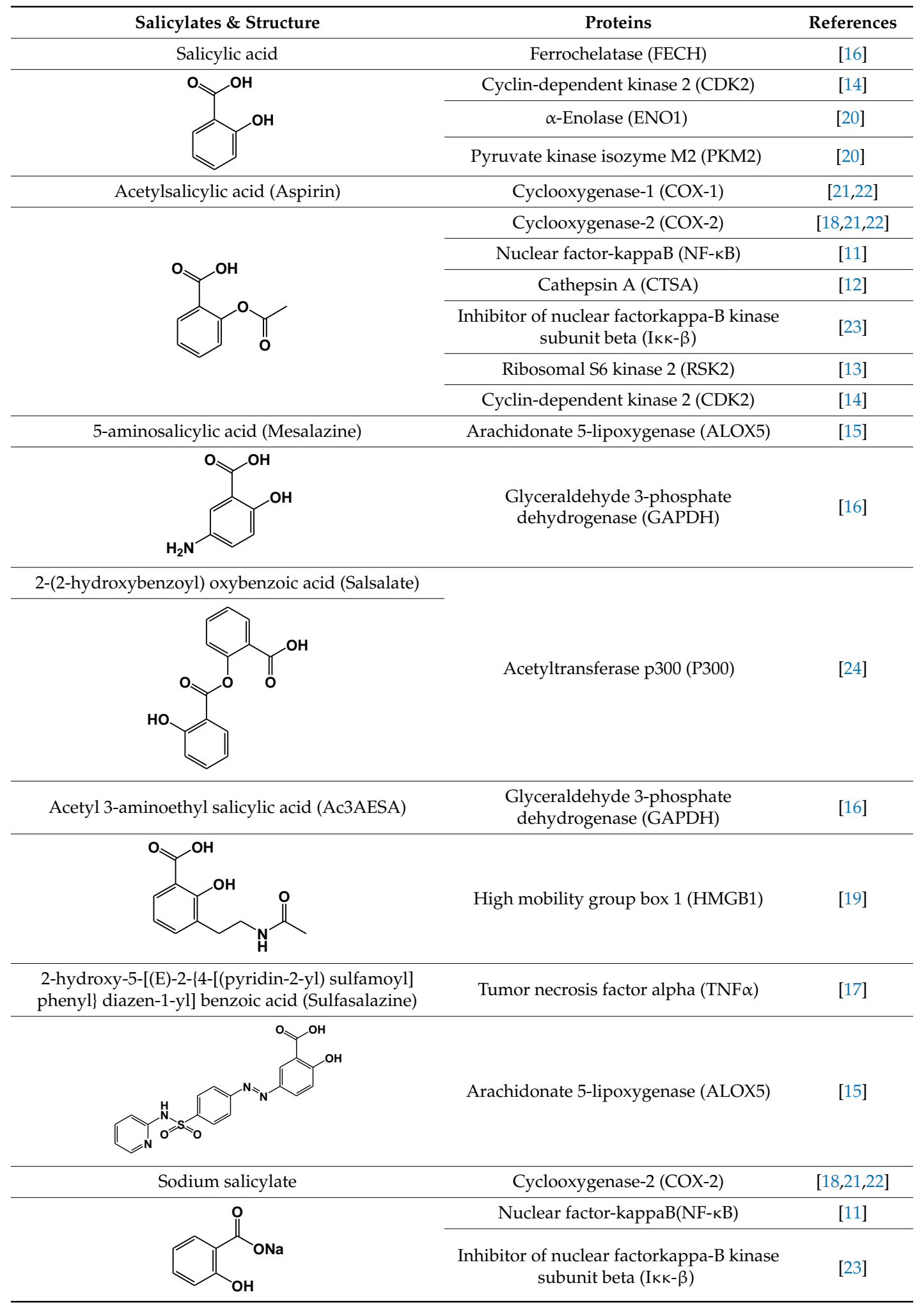


In this review, we focus on some natural salicylates, amorfrutin, ginkgolic acid, grifolic acid, tetrahydrocannabinolic acid, and cannabidiolic acid and discuss their multitarget inhibitory activities and pharmacological role in human disease (Figure 1). Amorfrutins are natural salicylates isolated from Amorpha fruticosa [25] and Glycyrrhiza foetida [26]. Different types of amorfrutins (A-D) are identified [27]. These amorfrutins are involved in many biological activities thus increasing the interest on it. The phenolic compound ginkgolic acids are found in leaves and fruits of Ginkgo biloba [28]. These are chemically 2-hydroxy-6-alkylbenzoic acids. Different ginkgolic acids structure such as C13:0, C15:1, and C17:1 have been designated according to their alkyl chain carbon number [29]. Recent studies suggest that ginkgolic acids have an anticancer property and some other pharmacological role so this compound may be a good target for drug development in human disease. The natural salicylate grifolic acid is isolated from the fruiting bodies of Albatrellus confluens fungus and this compound is a derivative of grifolin [30]. Grifolin shows anticancer activity in different types of cancer by inducing apoptosis and arrest of cell growth [31-35]. Some research suggests that grifolic acid also has anticancer activity [30,36]. Cannabis sativa $\mathrm{L}$. is a medicinal plant that is rich in cannabinoids [37]. $\Delta^{9}$-tetrahydrocannabinolic acid ( $\Delta^{9}$-THCA) and cannabidiolic acid (CBDA) are the most abundant cannabinoids in C. sativa L. and these are the acidic form of $\Delta^{9}$-THC and CBD respectively [38,39]. Besides the popular cannabinoids (THC and CBD), recently the other cannabinoids like $\Delta^{9}$-THCA and $\mathrm{CBDA}$ are gaining attention and interest from researchers due to their biological activities.

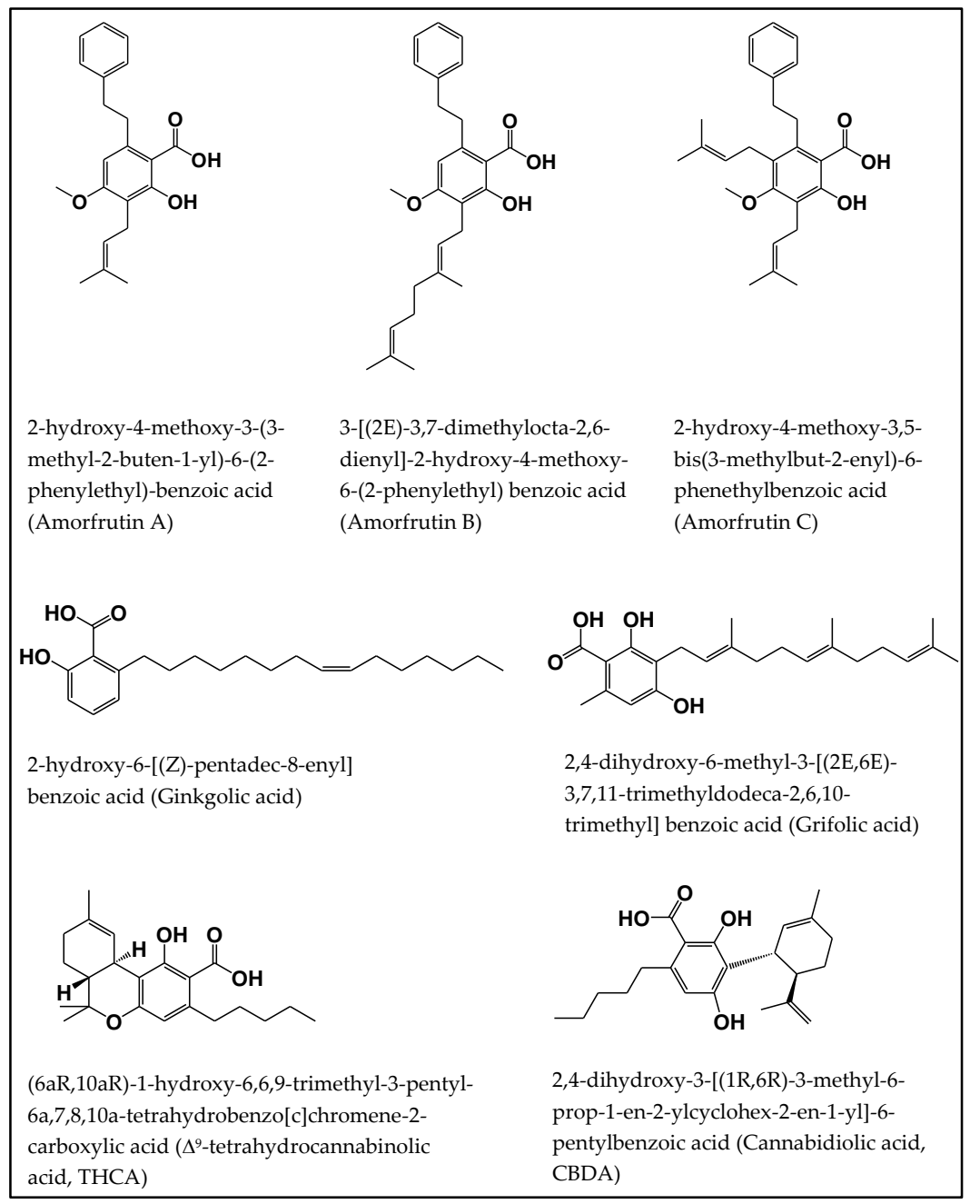

Figure 1. Chemical structures of our focused natural salicylates. Distinct phenyl moieties are contained in amorfrutins (A, B and C), THCA and CBDA, whereas fatty acids-based residues are contained in amorfrutins (A, B and C), gingkolic acid, grifolic acids, THCA and CBDA. 


\section{Pharmacological Roles of Natural Salicylates with Targets}

\subsection{Amorfrutins}

Recent studies indicate that amorfrutins show various pharmacological effects including antidiabetic [40,41], anticancer [28], and anti-inflammatory [42] activities (Table 2).

Table 2. Source, biological activities, and mechanism of action of our focused natural salicylates.

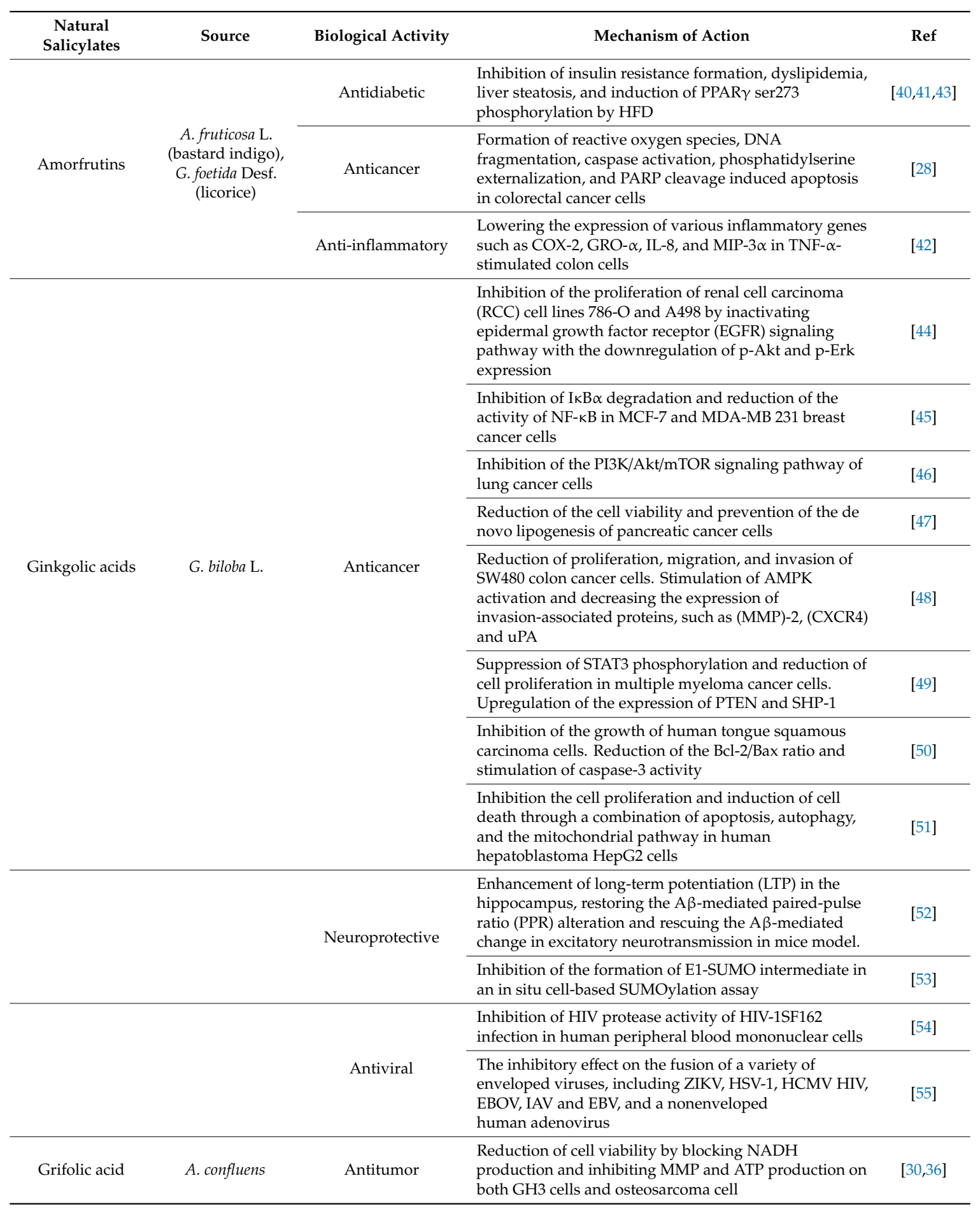


Table 2. Cont.

\begin{tabular}{|c|c|c|c|c|}
\hline $\begin{array}{c}\text { Natural } \\
\text { Salicylates }\end{array}$ & Source & Biological Activity & Mechanism of Action & Ref \\
\hline \multirow[t]{4}{*}{$\begin{array}{l}\text { Tetrahydro- } \\
\text { cannabinolic acid } \\
\text { (THCA) }\end{array}$} & \multirow[t]{2}{*}{ C. sativa } & Immunomodulatory & $\begin{array}{l}\text { Targeting PC-PLC enzymatic activity in phospholipids } \\
\text { metabolism and inhibition of tumor TNF-a release from } \\
\text { LPS-activated U937 macrophages and peripheral blood } \\
\text { macrophages }\end{array}$ & [56] \\
\hline & & Anti-inflammatory & $\begin{array}{l}\text { Inhibition COX1 and COX2 expression, Reduction of } \\
\text { prostaglandin production also inhibition MMP9 } \\
\text { expression in colon cancer cell }\end{array}$ & {$[57,58]$} \\
\hline & & \multirow{2}{*}{ Neuroprotective } & $\begin{array}{l}\text { Reduction of dopaminergic neurons degenerative effect } \\
\text { of MPP+, increasing cell survival in mice } \\
\text { mesencephalic cultures }\end{array}$ & [59] \\
\hline & & & $\begin{array}{l}\text { Reduction of degenerative effects of 3-NPA, through a } \\
\text { PPAR } \gamma \text {-dependent pathway in N2a cell and in vivo } \\
\text { mice model }\end{array}$ & [60] \\
\hline \multirow{3}{*}{$\begin{array}{l}\text { Cannabidiolic } \\
\text { acid (CBDA) }\end{array}$} & \multirow{2}{*}{ C. sativa } & \multirow{2}{*}{ Anticancer } & $\begin{array}{l}\text { Inhibition of the transcriptional activities of both } \\
\text { activator protein I (AP-I) and peroxisome proliferator- } \\
\text { activated receptor PPAR } \beta / \delta \text { in breast cancer cell }\end{array}$ & [63] \\
\hline & & & $\begin{array}{l}\text { Inhibition of human breast cancer cell metastasis by } \\
\text { suppressing COX } 2 \text { and proto-oncogene c-Fos expression } \\
\text { and upregulation of the expression of SHARP1 }\end{array}$ & [64-66] \\
\hline & & Anti-inflammatory & $\begin{array}{l}\text { Stimulation of vanilloid } 1 \text { and ankyrin } 1 \text { transient } \\
\text { receptor potential (TRP) channels (TRPV1 and TRPA1, } \\
\text { respectively), and antagonize a receptor, the Transient } \\
\text { Receptor Potential Cation Channel Subfamily M } \\
\text { Member } 8 \text { (TRPM8) in HEK } 293 \text { cells }\end{array}$ & [67] \\
\hline
\end{tabular}

\subsubsection{Antidiabetic Property}

Type-2 diabetes is a worldwide increasing metabolic disease. For its prevention and treatment, new strategies are needed to develop. The gene expression of metabolism, inflammation, and other pathways in adipocytes is mainly regulated by the nuclear receptor PPAR $\gamma$ (peroxisome proliferator-activated receptor gamma) [73]. Weidner et al. suggest that amorfrutins perform as selective PPAR $\gamma$ modulators (SPPAR $\gamma \mathrm{Ms}$ ) which increase favorable changes in glucose metabolism and lipid profiles. Amorfrutins were isolated from the edible roots of licorice G. foetida and from the fruit of another legume A. fruticosa which is used as an ingredient in some condiments. In a competitive time-resolved fluorescent resonance energy transfer (TR-FRET) assay, the four amorfrutins showed the distinct Ki values selectivity for PPAR $\gamma$ subtypes (range from 236 to $354 \mathrm{nM}$ ), compared to other PPAR subtypes. Amorfrutins can regulate PPAR $\gamma$ gene expression selectively in adipocytes. Evaluation of in vivo effects in Type 2 diabetes mouse model suggested that amorfrutins act as antidiabetic agent [40]. Amorfrutin A and B inhibit insulin resistance formation, dyslipidemia, and liver steatosis through activation of PPAR $\gamma$ via ser273 phosphorylation $[40,41,43]$. These experiments together suggest that selective PPAR $\gamma$-activation by dietary amorfrutins can develop a promising approach to fight against type- 2 diabetes.

\subsubsection{Anticancer Activity}

Today, cancer is a global concern, because of its leading position of causing death with about 8.8 million deaths and 18 million new cases per year [74,75]. Many different chemotherapeutic treatments are used for cancer, but those have some toxic side effects [76], so it is urgent to develop new promising anticancer agents. As an alternative approach, the clinical use of natural products or their 
synthetic analogs is considered to develop anticancer agents [77,78]. A recent study on amorfrutin C shows that it acts as an anticancer agent by inducing apoptosis and inhibiting proliferation of different cancer cell lines, including human colorectal cancer cells (HT-29 and T84), prostate cancer (PC-3), and breast cancer (MCF7) cells ( $\mathrm{IC}_{50}$ values ranging from 8 to $16 \mu \mathrm{M}$ in these cancer cell lines) through targeting mitochondria. Treatment of HT-29 cells with amorfrutin C induced apoptotic cell death accompanied by the formation of reactive oxygen species, DNA fragmentation, caspase activation, phosphatidylserine externalization, and poly (ADP-ribose) polymerase (PARP) cleavage. Synergistic apoptosis induction of amorfrutin $C$ with alpha Fas receptor ligand ( $\alpha$ FAS) and TNF-related apoptosis inducing ligand (TRAIL) in HT-29 cells suggest the stimulation of death receptor signaling pathway [28]. Taken together, amorfrutin $\mathrm{C}$ represents a promising candidate for anticancer drug development; however, its cellular target is not clearly identified.

\subsubsection{Anti-Inflammatory Effect}

Although amorfrutin's target PPAR $\gamma$ is the key regulator in metabolic regulation, it can inhibit inflammatory gene expression by a different mechanism including (i) direct interaction with transcription factor NF-KB, (ii) regulation of mitogen-activated protein kinase (MAPK) pathway by reducing p38 activation [79], (iii) suppression of inflammatory genes expression via SUMOylation-dependent pathway [80], and (iv) activating E3 ubiquitin ligase activity of PPAR $\gamma$ [81]. So, for the treatment of inflammatory disease, many clinical studies have been developed to evaluate the anti-inflammatory activity of PPAR $\gamma$ ligands. Amorfrutin A treatment in TNF- $\alpha$ - stimulated colon cells resulted in lower expression of various proinflammatory genes such as COX-2, GRO- $\alpha, I L-8$, and MIP-3 $\alpha$ suggesting that amorfrutins may have a beneficial effect for inflammatory disease, such as ulcerative colitis, via targeting PPAR $\gamma$ [42].

\subsection{Ginkgolic Acids}

Some recent studies suggest that ginkgolic acid (GA) may have a good candidate for developing a drug in different human diseases targeting various proteins. Its pharmacological role includes anticancer activity [44-51,82,83], neuroprotective role [52,53], and antimicrobial activity $[54,55,84]$ (Table 2).

\subsubsection{Anticancer Activity}

GA inhibited the proliferation of human Hep-2 cancer cells with the $\mathrm{IC}_{50}$ value of $20 \mu \mathrm{M}$ [82] and induced cell death in human hepatoblastoma HepG2 cells via inducing apoptosis, autophagy, and mitochondrial dysfunction [51]. Bcl-2 is an antiapoptotic protein located in the outer membrane of mitochondria and plays its role by inhibiting cytochrome release and also caspase- 3 activity; on the other hand, the proapototic protein Bax helps to release cytochrome and stimulates caspase-mediated cell death. So, lowering the Bcl-2/Bax ratio can be a good target for anticancer drug development [85-89]. Human Hep-2 cells and Tac 8113 cells (human tongue squamous carcinoma cell line) treated by GA showed that reduced the Bcl-2/Bax ratio, and enhanced caspase- 3 activity. GA also inhibited the growth of Tac8113 cells in a time- and dose-dependent manner with the $\mathrm{IC}_{50}$ value of $40 \mu \mathrm{M}$ [50]. Oncogenic transcription factor STAT3 (Signal transducer and activator of transcription 3) involves in the development of hematological malignancies in multiple myeloma. Phosphorylation of STAT3 stimulates different cancer related proteins, such as Bcl-xl, Bcl-2 (tumorigenesis), Cyclin D1 (proliferation), MMP-9 (invasion), and VEGF (angiogenesis) [90-92]. Different tyrosine kinase called janus-like kinase (JAK), including JAK1, JAK2, JAK3, and TYK2 positively regulates the STAT3 pathway [93,94]; on the other hand, different protein tyrosine phosphatases (PTPs), including PTEN and SHP-1, negatively regulate STAT3 activation $[95,96]$. Thus, recent studies have been focused on the suppression of STAT3 activity for cancer treatment. Ginkgolic acid C (GAC) 17:1 suppressed STAT3 phosphorylation in multiple myeloma U266 cells and significantly reduced cell proliferation in both U266 and MM.1S cells in a dose- and time-dependent manner. GAC 17:1 upregulated the expression of PTEN and SHP-1 in 
protein and mRNA level, whereas it down-regulated the expression of STAT3-regulated gene products, such as Bcl-2, Bcl-xL, survivin, IAP-1, COX-2, cyclin D1, VEGF, MMP-9, and MMP-2, in multiple myeloma cells [49]. In SW480 colon cancer cells, GA treatment inhibited proliferation, migration, and invasion by stimulating adenosine monophosphate activated protein kinase (AMPK) activation and decreasing the expression of invasion-associated proteins such as matrix metalloproteinase-2 (MMP-2), C-X-C chemokine receptor type 4 (CXCR4), and urinary-type plasminogen activator (uPA) [48]. In lung cancer cells, GA treatment ameliorated migration and invasion by inhibition of the PI3K/Akt/mTOR signaling pathway [46]. GA reduced the viability of pancreatic cancer cells Panc-1 and BxPC-3. Both in vitro and in vivo results suggested that GA prevented the de novo lipogenesis of pancreatic cancer cells by inducing the activation of AMPK signaling pathway and suppressed several key enzymes (e.g., acetyl-CoA carboxylase [ACC], fatty acid synthase [FASN]) expression involved in lipogenesis [47]. In MCF-7 and MDA-MB 231 breast cancer cells, GA treatment showed antimigratory effects and inhibited the sumoylation of NEMO leading to inhibition of IкB $\alpha$ degradation. Consequently, reduced activity of NF- $\mathrm{KB}$ leads to the downregulation of NF- $\mathrm{kB}$ target genes, $\mathrm{uPA}$, plasminogen activator inhibitor-1 (PAI-1), CXCR4, and MMP-9 [45]. GA inhibited the proliferation of renal cell carcinoma (RCC) cell lines 786-O and A498 by inactivating the epidermal growth factor receptor (EGFR) signaling pathway with the downregulation of p-Akt and p-Erk expression. Thus, GA targets different signaling pathways, including STAT3 pathway, PI3K/Akt/mTOR signaling pathway, and EGFR signaling pathway and causes downregulation of their associated proteins [44]. Microsomal prostaglandin E2 synthase-1 (mPGES-1)-derived prostaglandin $\mathrm{E}_{2}\left(\mathrm{PGE}_{2}\right)$ and leukotrienes (LTs) are both crucial mediators in the development of inflammation-associated cancer. GA inhibited the activity of mPGES-1 $\left(\mathrm{IC}_{50}=0.7 \mu \mathrm{M}\right)$ and 5-lipoxygenase $\left(\mathrm{IC}_{50}=0.2 \mu \mathrm{M}\right)$, the key enzyme in LT biosynthesis [83]. So, GA can be an efficient target for developing cancer treatment.

\subsubsection{Neuroprotective Activity}

The aberrant SUMOylation process has been involved in neurodegenerative diseases [97]. GA directly binds SUMO-activating enzyme (E1) and inhibits the formation of E1-SUMO intermediate [53]. Neurodegenerative disorder Alzheimer's disease (AD) is identified by the continuous loss of neurons, deposition of insoluble aggregates of two proteins in the brain, amyloid- $\beta$ (A $\beta$ ) and the microtubule-associated protein tau (MAPT). Synaptic impairment occurs in this disease affecting the hippocampus and entorhinal cortex brain areas thus, hampered cognitive process and memory formation $[98,99]$. GA enhanced long-term potentiation (LTP) in the hippocampus, restored $A \beta$-mediated paired-pulse ratio (PPR) alteration, and rescued $A \beta$-mediated change in excitatory neurotransmission. The neuroprotective role of GA against $A \beta$-induced synaptic deterioration representing an effective approach to $\mathrm{AD}$ treatment [52].

\subsubsection{Antiviral Activity}

HIV-1 protease plays an important role in the HIV viral life cycle as it breaks down the newly synthesized polyproteins to create the mature proteins of an HIV virion. Thus, HIV protease inhibitors (PIs) are very effective antiviral drugs that can reduce the morbidity and mortality of AIDS patients, thus significantly prolong their life [100]. GA inhibited HIV protease activity in a concentration-dependent manner with the $\mathrm{IC}_{50}$ of fewer than $30 \mu \mathrm{g} / \mathrm{mL}$ in the cell-free system and inhibited HIV-1SF162 infection in human peripheral blood mononuclear cells (PBMCs) in a concentration-dependent manner (50 and $100 \mu \mathrm{g} / \mathrm{mL}$ ) [54]. GA showed an inhibitory effect on the fusion of a variety of enveloped viruses, including Zika virus (ZIKV), Herpes simplex virus type 1 (HSV-1), human cytomegalovirus (HCMV), human immune deficiency virus (HIV), Ebola virus (EBOV), influenza A virus (IAV), and Epstein Barr virus (EBV) and also inhibited a nonenveloped human adenovirus. In the case of postinfection, GA inhibited HSV-1 and CMV replication targeting protein and DNA synthesis by a secondary mechanism [55]. GA targets HIV protease enzyme and viral polymerase gene. As a PI, GA can play an important role in antiviral drug development. 


\subsection{Grifolic Acids}

Grifolic acid is isolated from the fruiting bodies of $A$. confluens fungus and this compound is a derivative of grifolin [30]. This grifolin has anticancer properties [31-35]. Its acidic form grifolic acid is shown to have anticancer activity [30,36] (Table 2).

Antitumor Activity

Grifolic acid treatment reduced cell viability on $\mathrm{GH} 3$ cells, the rat anterior pituitary adenoma cells, in a dose- and time-dependent manner (from $2.5 \mu \mathrm{M}$ to $20 \mu \mathrm{M}$ ) and resulted in total cell death after $6 \mathrm{~h}$ treatment with $20 \mu \mathrm{M}$. Mitochondrial membrane potential (MMP) production was significantly decreased by grifolic acid $(20 \mu \mathrm{M}) 5 \mathrm{~min}$ after incubation and caused the maximal effect in $20 \mathrm{~min}$. Grifolic acid also significantly decreased the cellular ATP level in GH3 cells. Without G-protein coupled receptor 120 (GPR120) activity, grifolic acid reduced GH3 adenoma cell viability by blocking NADH production in mitochondria, thereby decreasing MMP and ATP production [36]. Another report showed almost the same mechanism of grifolic acid in the case of osteosarcoma cell death. Grifolic acid treatment reduced cell viability in a time- and dose-dependent manner on four osteosarcoma cell lines U-2 OS, MG-63, Saos-2, and 143B. Total cell death occurred $6 \mathrm{~h}$ after treatment with $30 \mu \mathrm{M}$ grifolic acid. In the animal model, intratumoral injection of grifolic acid increased necrosis of human osteosarcoma xenograft in nude mice without any observable toxicity [30].

\subsection{Tetrahydrocannabinolic Acid (THCA) and Cannabidiolic Acid (CBDA)}

The acidic forms of THC and CBD are THCA and CBDA, respectively, and these are the most abundant cannabinoids in C. sativa L. [39]. Based on recent studies, two phytocannabinoids THCA and CBDA may be a good candidate for developing an efficient drug for different human diseases treatment. The pharmacological role of THCA including immunomodulatory effect [56], anti-inflammatory role [57,58], neuroprotective role [59,60], and antineoplastic activity [61,62].

Based on in silico analysis, the drug likeness score of CBDA predicted it as possible G protein-coupled receptors (GPCRs) ligands, ion channel modulators, kinase inhibitors, nuclear receptor ligands, and protease inhibitors with moderately active in all bioactive scores [101]. According to recent studies CBDA has anticancer activity [63-66], anti-inflammatory activity [67-69], antiemetic effect [70,71], and anticonvulsant effect [72]. Due to its pharmacological property (Table 2), it is getting more and more attention.

\subsubsection{Immunomodulatory Effect}

The cannabinoid receptor $\mathrm{CB} 1$ and $\mathrm{CB} 2$ are involved in immunomodulating actions of cannabinoids [102-105]. Other studies suggest that metabolic pathways and noncannabinoid receptors are involved with immunomodulatory effect of cannabinoids [106-108]. Importantly, agonists of cannabinoid receptor have a psychotropic effect [107]. Therefore, there is an effort to identify the compounds which have therapeutic effects but that are not able to activate CB1 and CB2 to avoid the psychotropic effect. THCA showed their immunomodulatory effect through a different metabolic pathway, without activating CB1 and CB2 [56]. THCA targeted phosphatidyl choline specific phospholipase C (PC-PLC) enzymatic activity in phospholipids metabolism and inhibits proinflammatory cytokine tumor necrosis factor alpha (TNF- $\alpha$ ) release from lipopolysaccharide (LPS)-activated U937 macrophages and peripheral blood macrophages in a dose-dependent manner with the $\mathrm{EC}_{50}$ value of approximately $50 \mu \mathrm{M}$.

\subsubsection{Anti-Inflammatory Role}

Cyclooxygenase 1 (COX1) and cyclooxygenase 2 (COX2) are essential to produce prostaglandins which are important for the inflammatory reaction. THCA inhibited COX1 ( $\mathrm{IC}_{50}$ of $\left.1700 \mu \mathrm{M}\right)$ and COX2 ( $\mathrm{IC}_{50}$ of $\left.630 \mu \mathrm{M}\right)$ using an enzyme-based in vitro assay and human colon adenocarcinoma HT29 
cell line. Prostaglandin production was also inhibited $(10 \%$ inhibition, $62.5 \mu \mathrm{M})$ in HT29 cell line by THCA [57]. Another report showed that THCA inhibited COX2 expression in a dose-dependent manner in three colon cancer cell lines HCT116, HT29, and CaCO2. In addition, THCA inhibited Matrix metallopeptidase 9 (MMP-9) expression in colon cell lines indicating that THCA plays an efficient role against colon inflammation [58].

CBDA exerted anti-inflammatory activity in receptor level by stimulating vanilloid 1 and ankyrin 1 transient receptor potential (TRP) channels (TRPV1 and TRPA1, respectively) or by antagonizing the Transient Receptor Potential Cation Channel Subfamily M Member 8 (TRPM8) with IC $_{50}$ value ranging 0.9-1.6 $\mu \mathrm{M}$ [67]. COX2 is mainly involved in an inflammatory response. CBDA acts as a selective inhibitor of COX2 with an $\mathrm{IC}_{50}$ value of approximately $2 \mu \mathrm{M}$ [68]. Intraperitoneal administration of rodent with CBDA $(10 \mu \mathrm{g} / \mathrm{kg}) 60 \mathrm{~min}$ prior to treatment with carrageenan produced anti-inflammatory effects in a dose-dependent manner but orally did not [69].

\subsubsection{Neuroprotective Role}

Noncompetitive inhibitors of the NADH ubiquinone reductase (complex 1), such as 1-methyl-4phenyl pyridinium $\left(\mathrm{MPP}^{+}\right)$, are used as a model compound in dopaminergic neuronal degeneration to study Parkinson's disease (PD). THCA reduced the degenerative effect of $\mathrm{MPP}^{+}$in dopaminergic neurons and increased cell survival at the highest tested dose of $10 \mu \mathrm{M}$ in mice mesencephalic cultures [59]. Another model compound 3-nitropropionic acid (3-NPA) is used in the research of huntingtin disease (HD) which acts as a complex II inhibitor of the mitochondrial respiratory chain, resulting in progressive loss of locomotor and striatal degeneration. THCA mitigated degenerative effects of 3-NPA, through a PPAR $\gamma$-dependent pathway in N2a cell [60].

Phytocannabinoids canabigerol (CBG) and cannabidivarin (CBDV) are the most promising candidates as neuroprotectants, while $\triangle 9$-tetrahydrocannabivarin $(\triangle 9$-THCV), $\triangle 9$-THCA, cannabichromene (CBC), and cannabinol $(\mathrm{CBN})$ have limited but encouraging data as neuroprotectants. However, little is known with neuroprotective potential of CBDA [109].

\subsubsection{Anticancer Activity}

THCA inhibited cell proliferation in various prostate carcinoma cell (PCC) lines, including (i) androgen-receptor positive cells (LNCaP and 22RV1) with $\mathrm{IC}_{50}$ of $22.1 \pm 2 \mu \mathrm{M}$ or $17.1 \pm 1 \mu \mathrm{M}$ in the presence or absence of serum, respectively, (ii) androgen-receptor negative cells (DU-145 and PC-3) with $\mathrm{IC}_{50}$ of $>25 \mu \mathrm{M}(21.9 \%$ inhibition) or $21.6 \pm 2 \mu \mathrm{M}$ in the presence or absence of serum, respectively [62]. Cell proliferation of two different human breast carcinoma (HBC) cells, triple-negative MDA-MB-231 and HER2-negative MCF-7, were inhibited with $\mathrm{IC}_{50}$ value of $18.2 \pm 5 \mu \mathrm{M}$ and $9.8 \pm 0.4 \mu \mathrm{M}$, respectively [61].

CBDA reduced COX2 expression in triple-negative MDA-MB-231 human breast cancer cell with a concentration of $5 \mu \mathrm{M}$ by abrogating the transcriptional activities of both activator protein-I (AP-I) and peroxisome proliferator-activated receptor PPAR $\beta / \delta$ [63]. CBDA inhibited human breast cancer cell metastasis by suppressing COX2 and proto-oncogene c-Fos expression and upregulating the expression of SHARP1(1.72-fold), a suppressor of breast cancer metastasis [63-66].

\subsubsection{Antiemetic Effect and Anticonvulsant Effect}

5-HT1A receptors control the antinausea effects of CBDA. In vivo mice study showed that CBDA inhibited vomiting caused by toxins and induced 5-HT1A receptor activity [70,71]. The pharmacokinetics of phytocannabinoid acids (including CBDA with others) showed that plasma level absorption occurred rapidly, and the brain/plasma ratio was very low. However, when CBDA was administered in an alternate Tween 80-based vehicle, the value of the brain/plasma ratio was 1.9 and in Scn $1 a^{\mathrm{RX} /+}$ mouse model of Dravet syndrome, and CBDA showed potent anticonvulsant activity [72]. 


\section{Conclusions}

Plant derived natural compounds are used throughout the world for medicinal purposes. Plant derived salicylates target many human proteins and can play prominent roles in human disease treatment. Initially, researchers focused on acetyl salicylate (aspirin) and showed that it can be a good target for drug development for many human diseases. Recent findings suggest that many natural salicylates have pharmacological roles. Our focused salicylates amorfrutins, ginkgolic acid, grifolic acid, THCA, and CBDA target different human proteins and pathways. It appears clear that these natural salicylates may be promising natural compounds in treating different human diseases. Some medicinal plants and natural products showed relevant results in clinical trials [110-112]. However, there are very limited clinical trials available with these salicylates. Our review suggests that further clinical trials with different salicylates on different human diseases will be needed based on many preclinical results with amorfrutins (antidiabetic, anticancer, and anti-inflammatory activities), ginkgolic acid (anticancer, neuroprotective, and antiviral activities), grifolic acid (antitumor activity), THCA (immunomodulatory, anti-inflammatory, neuroprotective, and antineoplastic activities), and CBDA (anticancer, anti-inflammatory, antiemetic, and anticonvulsant activities).

Funding: This work was supported by grants from Basic Research Program through the National Research Foundation of Korea (NRF) grant funded by Korea government (MSIT) (2019R1F1A1060416) and from the Nature Bioindustry Technology Development and Enterprise Support Project (BTD \& ESP) in Gyeongsangbuk-do. The APC was funded by (BTD \& ESP) in Gyeongsangbuk-do.

Conflicts of Interest: The authors declare no conflict of interest.

\section{References}

1. Vlot, A.C.; Dempsey, D.A.; Klessig, D.F. Salicylic acid, a multifaceted hormone to combat disease. Annu. Rev. Phytopathol. 2009, 47, 177-206. [CrossRef] [PubMed]

2. Hedner, T.; Everts, B. The early clinical history of salicylates in rheumatology and pain. Clin. Rheumatol. 1998, 17, 17-25. [CrossRef] [PubMed]

3. Fecka, I. Qualitative and quantitative determination of hydrolysable tannins and other polyphenols in herbal products from meadowsweet and dog rose. Phytochem. Anal. 2009, 20,177-190. [CrossRef]

4. Pino, J.A.; Mesa, J.; Muñoz, Y.; Martí, M.P.; Marbot, R. Volatile Components from Mango (Mangifera indica L.) Cultivars. J. Agric. Food Chem. 2005, 53, 2213-2223. [CrossRef] [PubMed]

5. Towers, G.; Tse, A.; Maass, W. Phenolic acids and phenolic glycosides of Gaultheria species. Phytochem. 1966, 5, 677-681. [CrossRef]

6. Yilmaz, N.; Yayli, N.; Misir, G.; Karaoglu, S. Chemical composition and antimicrobial activities of the essential oils of Viburnum opulus, Viburnum lantana and Viburnum oriental. Asian J. Chem. 2008, 20, 3324-3330.

7. Klessig, D.F.; Tian, M.; Choi, H.W. Multiple Targets of Salicylic Acid and Its Derivatives in Plants and Animals. Front. Immunol. 2016, 7, 206. [CrossRef]

8. Anthony, J.C.; Breitner, J.C.S.; Zandi, P.P.; Meyer, M.R.; Jurasova, I.; Norton, M.C.; Stone, S.V. Reduced prevalence of AD in users of NSAIDs and H2 receptor antagonists: The Cache County Study. Neurology 2000, 54, 2066-2071. [CrossRef]

9. Thun, M.J.; Jacobs, E.J.; Patrono, C. The role of aspirin in cancer prevention. Nat. Rev. Clin. Oncol. 2012, 9, 259-267. [CrossRef]

10. Shirakawa, K.; Wang, L.; Man, N.; Maksimoska, J.; Sorum, A.W.; Lim, H.W.; Lee, I.S.; Shimazu, T.; Newman, J.C.; Schröder, S.; et al. Salicylate, diflunisal and their metabolites inhibit CBP/p300 and exhibit anticancer activity. eLife 2016, 5, e11156. [CrossRef]

11. Kopp, E.; Ghosh, S. Inhibition of NF-kB by Sodium Salicylate and Aspirin. Science 1994, 265, 956-959. [CrossRef] [PubMed]

12. Ostrowska, H. Inhibition of human platelet cathepsin A by non-steroidal anti-inflammatory drugs-in vitro study. Pol. J. Pharmacol. 1996, 48, 113-116. [PubMed]

13. Stevenson, M.A.; Zhao, M.J.; Asea, A.; Coleman, C.N.; Calderwood, S.K. Salicylic Acid and Aspirin Inhibit the Activity of RSK2 Kinase and Repress RSK2-Dependent Transcription of Cyclic AMP Response Element Binding Protein- and NF-kB-Responsive Genes. J. Immunol. 1999, 163, 5608. [PubMed] 
14. Dachineni, R.; Ai, G.; Kumar, D.R.; Sadhu, S.S.; Tummala, H.; Bhat, G.J. Cyclin A2 and CDK2 as Novel Targets of Aspirin and Salicylic Acid: A Potential Role in Cancer Prevention. Mol. Cancer Res. 2016, 14, 241-252. [CrossRef] [PubMed]

15. Nielsen, O.H.; Bukhave, K.; Elmgreen, J.; Ahnfelt-Rønne, I. Inhibition of 5-lipoxygenase pathway of arachidonic acid metabolism in human neutrophils by sulfasalazine and 5-aminosalicylic acid. Dig. Dis. Sci. 1987, 32, 577-582. [CrossRef] [PubMed]

16. Choi, H.W.; Tian, M.; Manohar, M.; Harraz, M.M.; Park, S.W.; Schroeder, F.C.; Snyder, S.H.; Klessig, D.F. Human GAPDH Is a Target of Aspirin's Primary Metabolite Salicylic Acid and Its Derivatives. PLoS ONE 2015, 10, e0143447. [CrossRef] [PubMed]

17. Shanahan, F.; Niederlehner, A.; Carramanzana, N.; Anton, P. Sulfasalazine inhibits the binding of TNF $\alpha$ to its receptor. Immunopharmacology 1990, 20, 217-224. [CrossRef]

18. Mitchell, J.A.; Saunders, M.; Barnes, P.J.; Newton, R.; Belvisi, M.G. Sodium salicylate inhibits cyclo-oxygenase-2 activity independently of transcription factor (nuclear factor kappaB) activation: Role of arachidonic acid. Mol. Pharmacol. 1997, 51, 907-912. [CrossRef]

19. Choi, H.W.; Tian, M.; Song, F.; Venereau, E.; Preti, A.; Park, S.W.; Hamilton, K.; Swapna, G.V.T.; Manohar, M.; Moreau, M.; et al. Aspirin's Active Metabolite Salicylic Acid Targets High Mobility Group Box 1 to Modulate Inflammatory Responses. Mol. Med. 2015, 21, 526-535. [CrossRef]

20. Choi, H.W.; Wang, L.; Powell, A.F.; Strickler, S.R.; Wang, D.; Dempsey, D.A.; Schroeder, F.C.; Klessig, D.F. A genome-wide screen for human salicylic acid (SA)-binding proteins reveals targets through which SA may influence development of various diseases. Sci. Rep. 2019, 9, 1-14. [CrossRef]

21. Vane, J.R. Inhibition of Prostaglandin Synthesis as a Mechanism of Action for Aspirin-like Drugs. Nat. New Biol. 1971, 231, 232-235. [CrossRef] [PubMed]

22. Mitchell, J.A.; Akarasereenont, P.; Thiemermann, C.; Flower, R.J.; Vane, J.R. Selectivity of nonsteroidal antiinflammatory drugs as inhibitors of constitutive and inducible cyclooxygenase. Proc. Natl. Acad. Sci. USA 1993, 90, 11693-11697. [CrossRef] [PubMed]

23. Yin, M.J.; Yamamoto, Y.; Gaynor, R.B. The anti-inflammatory agents aspirin and salicylate inhibit the activity of I(kappa)B kinase-beta. Nature 1998, 396, 77-80. [CrossRef] [PubMed]

24. Min, S.W.; Chen, X.; Tracy, T.E.; Li, Y.; Zhou, Y.; Wang, C.; Shirakawa, K.; Minami, S.S.; Defensor, E.; Mok, S.A.; et al. Critical role of acetylation in tau-mediated neurodegeneration and cognitive deficits. Nat. Med. 2015, 21, 1154-1162. [CrossRef]

25. Mitscher, L.A.; Park, Y.H.; AlShamma, A.; Hudson, P.; Haas, T. Amorfrutin A and B, bibenzyl antimicrobial agents from Amorpha fruticosa. Phytochemistry 1981, 20, 781-785. [CrossRef]

26. Isah, T. Rethinking Ginkgo biloba L.: Medicinal uses and conservation. Pharmacogn. Rev. 2015, 9, 140-148. [CrossRef]

27. Fujita, T.; Kuwahara, S.; Ogura, Y. Synthesis of amorfrutins B and D from amorfrutin A ethyl ester. Tetrahedron Lett. 2020, 61, 151477. [CrossRef]

28. Weidner, C.; Rousseau, M.; Micikas, R.J.; Fischer, C.; Plauth, A.; Wowro, S.J.; Siems, K.; Hetterling, G.; Kliem, M.; Schroeder, F.C.; et al. Amorfrutin C Induces Apoptosis and Inhibits Proliferation in Colon Cancer Cells through Targeting Mitochondria. J. Nat. Prod. 2016, 79, 2-12. [CrossRef]

29. He, X.G.; Bernart, M.W.; Nolan, G.S.; Lin, L.Z.; Lindenmaier, M.P. High-Performance Liquid Chromatography-Electrospray Ionization-Mass Spectrometry Study of Ginkgolic Acid in the leaves and Fruits of the Ginkgo Tree (Ginkgo biloba). J. Chromatogr. Sci. 2000, 38, 169-173. [CrossRef]

30. Zhao, Y.F.; Jiang, F.; Liang, X.Y.; Wei, L.-L.; Zhao, Y.Y.; Ma, Q.; Hu, Y.S.; Su, X. Grifolic acid causes osteosarcoma cell death in vitro and in tumor-bearing mice. Biomed. Pharmacother. 2018, 103, 1035-1042. [CrossRef]

31. Ye, M.; Liu, J.K.; Lu, Z.X.; Zhao, Y.; Liu, S.F.; Li, L.; Tan, M.; Weng, X.X.; Li, W.; Cao, Y. Grifolin, a potential antitumor natural product from the mushroomAlbatrellus confluens, inhibits tumor cell growth by inducing apoptosis in vitro. FEBS Lett. 2005, 579, 3437-3443. [CrossRef] [PubMed]

32. Jin, S.; Pang, R.P.; Shen, J.N.; Huang, G.; Wang, J.; Zhou, J.G. Grifolin induces apoptosis via inhibition of PI3K/AKT signalling pathway in human osteosarcoma cells. Apoptosis 2007, 12, 1317-1326. [CrossRef] [PubMed]

33. Luo, X.; Yang, L.; Xiao, L.; Xia, X.; Dong, X.; Zhong, J.; Liu, Y.; Li, N.; Chen, L.; Hongde, L.; et al. Grifolin directly targets ERK1/2 to epigenetically suppress cancer cell metastasis. Oncotarget 2015, 6, 42704-42716. [CrossRef] [PubMed] 
34. Che, X.; Yan, H.; Sun, H.; Dongol, S.; Wang, Y.; Lv, Q.; Jiang, J. Grifolin induces autophagic cell death by inhibiting the Akt/mTOR/S6K pathway in human ovarian cancer cells. Oncol. Rep. 2016, 36, 1041-1047. [CrossRef]

35. Wu, Z.; Li, Y. Grifolin exhibits anti-cancer activity by inhibiting the development and invasion of gastric tumor cells. Oncotarget 2017, 8, 21454-21460. [CrossRef]

36. Zhao, Y.F.; Zhang, L.; Yan, A.; Chen, D.; Xie, R.; Liu, Y.; Liang, X.; Zhao, Y.; Wei, L.; Yu, J.; et al. Grifolic acid induces GH3 adenoma cell death by inhibiting ATP production through a GPR120-independent mechanism. BMC Pharmacol. Toxicol. 2018, 19, 26. [CrossRef]

37. Andre, C.M.; Hausman, J.F.; Guerriero, G. Cannabis sativa: The Plant of the Thousand and One Molecules. Front. Plant Sci. 2016, 7, 19. [CrossRef]

38. Brighenti, V.; Pellati, F.; Steinbach, M.; Maran, D.; Benvenuti, S. Development of a new extraction technique and HPLC method for the analysis of non-psychoactive cannabinoids in fibre-type Cannabis sativa L. (hemp). J. Pharm. Biomed. Anal. 2017, 143, 228-236. [CrossRef]

39. Pellati, F.; Brighenti, V.; Sperlea, J.; Marchetti, L.; Bertelli, D.; Benvenuti, S. New Methods for the Comprehensive Analysis of Bioactive Compounds in Cannabis sativa L. (hemp). Molecules 2018, 23, 2639. [CrossRef]

40. Weidner, C.; De Groot, J.C.; Prasad, A.; Freiwald, A.; Quedenau, C.; Kliem, M.; Witzke, A.; Kodelja, V.; Han, C.; Giegold, S.; et al. Amorfrutins are potent antidiabetic dietary natural products. Proc. Natl. Acad. Sci. USA 2012, 109, 7257-7262. [CrossRef]

41. Weidner, C.; Wowro, S.J.; Freiwald, A.; Kawamoto, K.; Witzke, A.; Kliem, M.; Siems, K.; Müller-Kuhrt, L.; Schroeder, F.C.; Sauer, S. Amorfrutin B is an efficient natural peroxisome proliferator-activated receptor gamma (PPAR $\gamma$ ) agonist with potent glucose-lowering properties. Diabetology 2013, 56, 1802-1812. [CrossRef] [PubMed]

42. Fuhr, L.; Rousseau, M.; Plauth, A.; Schroeder, F.C.; Sauer, S. Amorfrutins Are Natural PPAR $\gamma$ Agonists with Potent Anti-inflammatory Properties. J. Nat. Prod. 2015, 78, 1160-1164. [CrossRef] [PubMed]

43. Meierhofer, D.; Weidner, C.; Hartmann, L.; Mayr, J.A.; Han, C.T.; Schroeder, F.C.; Sauer, S. Protein Sets Define Disease States and PredictIn VivoEffects of Drug Treatment. Mol. Cell. Proteom. 2013, 12, 1965-1979. [CrossRef] [PubMed]

44. Zhu, C.; Na, N.; Sheng, H.; Feng, B.; Wang, H.; Zhu, P.; Zhang, W.; Zhang, M.; Deng, Z. Ginkgolic acid inhibits the growth of renal cell carcinoma cells via inactivation of the EGFR signaling pathway. Exp. Ther. Med. 2020, 19, 2949-2956. [CrossRef]

45. Hamdoun, S.; Efferth, T. Ginkgolic acids inhibit migration in breast cancer cells by inhibition of NEMO sumoylation and NF-kB activity. Oncotarget 2017, 8, 35103-35115. [CrossRef]

46. Baek, S.H.; Ko, J.H.; Lee, J.H.; Kim, C.; Lee, H.; Nam, D.; Lee, J.; Lee, S.G.; Yang, W.M.; Um, J.Y.; et al. Ginkgolic Acid Inhibits Invasion and Migration and TGF- $\beta$-Induced EMT of Lung Cancer Cells through PI3K/Akt/mTOR Inactivation. J. Cell. Physiol. 2016, 232, 346-354. [CrossRef]

47. Ma, J.; Duan, W.; Han, S.; Lei, J.; Xu, Q.; Chen, X.; Jiang, Z.; Nan, L.; Li, J.; Chen, K.; et al. Ginkgolic acid suppresses the development of pancreatic cancer by inhibiting pathways driving lipogenesis. Oncotarget 2015, 6, 20993-21003. [CrossRef]

48. Qiao, L.; Zheng, J.; Jin, X.; Wei, G.; Wang, G.; Sun, X.; Li, X. Ginkgolic acid inhibits the invasiveness of colon cancer cells through AMPK activation. Oncol. Lett. 2017, 14, 5831-5838. [CrossRef]

49. Baek, S.H.; Lee, J.H.; Kim, C.; Ko, J.H.; Ryu, S.H.; Lee, S.G.; Yang, W.M.; Um, J.Y.; Chinnathambi, A.; Alharbi, S.A.; et al. Ginkgolic Acid C 17:1, Derived from Ginkgo biloba Leaves, Suppresses Constitutive and Inducible STAT3 Activation through Induction of PTEN and SHP-1 Tyrosine Phosphatase. Molecules 2017, 22, 276. [CrossRef]

50. Zhou, C.; Li, X.; Du, W.; Feng, Y.; Kong, X.; Li, Y.; Xiao, L.; Zhang, P. Antitumor Effects of Ginkgolic Acid in Human Cancer Cell Occur via Cell Cycle Arrest and Decrease the Bcl-2/Bax Ratio to Induce Apoptosis. Chemotherapy 2010, 56, 393-402. [CrossRef]

51. Qi, Q.; Xue, Y.; Lv, J.; Sun, D.; Du, J.; Cai, S.; Li, Y.; Gu, T.; Wang, M. Ginkgolic acids induce HepG2 cell death via a combination of apoptosis, autophagy and the mitochondrial pathway. Oncol. Lett. 2018, 15, 6400-6408. [CrossRef] [PubMed]

52. Mango, D.; Weisz, F.; Nisticò, R. Ginkgolic Acid Protects against A $\beta$-Induced Synaptic Dysfunction in the Hippocampus. Front. Pharmacol. 2016, 7, 401. [CrossRef] [PubMed] 
53. Fukuda, I.; Ito, A.; Hirai, G.; Nishimura, S.; Kawasaki, H.; Saitoh, H.; Kimura, K.I.; Sodeoka, M.; Yoshida, M. Ginkgolic Acid Inhibits Protein SUMOylation by Blocking Formation of the E1-SUMO Intermediate. Chem. Biol. 2009, 16, 133-140. [CrossRef] [PubMed]

54. Lü, J.M.; Yan, S.; Jamaluddin, S.; Weakley, S.M.; Liang, Z.; Siwak, E.B.; Yao, Q.; Chen, C. Ginkgolic acid inhibits HIV protease activity and HIV infection in vitro. Med. Sci. Monit. 2012, 18, 293-298. [CrossRef] [PubMed]

55. Borenstein, R.; Hanson, B.A.; Markosyan, R.M.; Gallo, E.S.; Narasipura, S.D.; Bhutta, M.; Shechter, O.; Lurain, N.S.; Cohen, F.S.; Al-Harthi, L.; et al. Ginkgolic acid inhibits fusion of enveloped viruses. Sci. Rep. 2020, 10, 4746. [CrossRef] [PubMed]

56. Verhoeckx, K.C.M.; Korthout, H.A.; Van Meeteren-Kreikamp, A.; Ehlert, K.A.; Wang, M.; Van Der Greef, J.; Rodenburg, R.J.T.; Witkamp, R.F. Unheated Cannabis sativa extracts and its major compound THC-acid have potential immuno-modulating properties not mediated by CB1 and CB2 receptor coupled pathways. Int. Immunopharmacol. 2006, 6, 656-665. [CrossRef] [PubMed]

57. Ruhaak, L.R.; Felth, J.; Karlsson, P.C.; Rafter, J.J.; Verpoorte, R.; Bohlin, L. Evaluation of the Cyclooxygenase Inhibiting Effects of Six Major Cannabinoids Isolated from Cannabis sativa. Biol. Pharm. Bull. 2011, 34, 774-778. [CrossRef]

58. Nallathambi, R.; Mazuz, M.; Ion, A.; Selvaraj, G.; Weininger, S.; Fridlender, M.; Nasser, A.; Sagee, O.; Kumari, P.; Nemichenizer, D.; et al. Anti-Inflammatory Activity in Colon Models Is Derived from $\Delta$ 9-Tetrahydrocannabinolic Acid That Interacts with Additional Compounds in Cannabis Extracts. Cannabis Cannabinoid Res. 2017, 2, 167-182. [CrossRef]

59. Moldzio, R.; Pacher, T.; Krewenka, C.; Kranner, B.; Novak, J.; Duvigneau, J.C.; Rausch, W.D. Effects of cannabinoids $\Delta(9)$-tetrahydrocannabinol, $\Delta(9)$-tetrahydrocannabinolic acid and cannabidiol in MPP+ affected murine mesencephalic cultures. Phytomedicine 2012, 19, 819-824. [CrossRef]

60. Nadal, X.; Del Río, C.; Casano, S.; Palomares, B.; Ferreiro-Vera, C.; Navarrete, C.; Sánchez-Carnerero, C.; Cantarero, I.; Bellido, M.L.; Meyer, S.; et al. Tetrahydrocannabinolic acid is a potent PPAR $\gamma$ agonist with neuroprotective activity. Br. J. Pharmacol. 2017, 174, 4263-4276. [CrossRef]

61. Ligresti, A.; Moriello, A.S.; Starowicz, K.; Matias, I.; Pisanti, S.; De Petrocellis, L.; Laezza, C.; Portella, G.; Bifulco, M.; Di Marzo, V. Antitumor Activity of Plant Cannabinoids with Emphasis on the Effect of Cannabidiol on Human Breast Carcinoma. J. Pharmacol. Exp. Ther. 2006, 318, 1375-1387. [CrossRef] [PubMed]

62. De Petrocellis, L.; Ligresti, A.; Schiano Moriello, A.; Iappelli, M.; Verde, R.; Stott, C.G.; Cristino, L.; Orlando, P.; Di Marzo, V. Non-THC cannabinoids inhibit prostate carcinoma growth in vitro and in vivo: Pro-apoptotic effects and underlying mechanisms. Br. J. Pharmacol. 2013, 168, 79-102. [CrossRef] [PubMed]

63. Hirao-Suzuki, M.; Takeda, S.; Koga, T.; Takiguchi, M.; Toda, A. Cannabidiolic acid dampens the expression of cyclooxygenase-2 in MDA-MB-231 breast cancer cells: Possible implication of the peroxisome proliferator-activated receptor $\beta / \delta$ abrogation. J. Toxicol. Sci. 2020, 45, 227-236. [CrossRef] [PubMed]

64. Takeda, S.; Okazaki, H.; Ikeda, E.; Abe, S.; Yoshioka, Y.; Watanabe, K.; Aramaki, H. Down-regulation of cyclooxygenase-2 (COX-2) by cannabidiolic acid in human breast cancer cells. J. Toxicol. Sci. 2014, 39, 711-716. [CrossRef]

65. Takeda, S.; Okajima, S.; Miyoshi, H.; Yoshida, K.; Okamoto, Y.; Okada, T.; Amamoto, T.; Watanabe, K.; Omiecinski, C.J.; Aramaki, H. Cannabidiolic acid, a major cannabinoid in fiber-type cannabis, is an inhibitor of MDA-MB-231 breast cancer cell migration. Toxicol. Lett. 2012, 214, 314-319. [CrossRef]

66. Suzuki, M.; Takeda, S.; Okazaki, H.; Watanabe, K.; Takiguchi, M.; Aramaki, H. Cannabidiolic Acid-Mediated Interference with AP-1 Transcriptional Activity in MDA-MB-231 Breast Cancer Cells. Nat. Prod. Commun. 2017, 12, 759-761. [CrossRef]

67. De Petrocellis, L.; Vellani, V.; Schiano-Moriello, A.; Marini, P.; Magherini, P.C.; Orlando, P.; Di Marzo, V. Plant-Derived Cannabinoids Modulate the Activity of Transient Receptor Potential Channels of Ankyrin Type-1 and Melastatin Type-8. J. Pharmacol. Exp. Ther. 2008, 325, 1007-1015. [CrossRef]

68. Takeda, S.; Misawa, K.; Yamamoto, I.; Watanabe, K. Cannabidiolic Acid as a Selective Cyclooxygenase-2 Inhibitory Component in Cannabis. Drug Metab. Dispos. 2008, 36, 1917-1921. [CrossRef]

69. Rock, E.M.; Limebeer, C.L.; Parker, L.A. Effect of cannabidiolic acid and $\Delta 9$-tetrahydrocannabinol on carrageenan-induced hyperalgesia and edema in a rodent model of inflammatory pain. Psychopharmacology 2018, 235, 3259-3271. [CrossRef] 
70. Rock, E.M.; Bolognini, D.; Limebeer, C.L.; Cascio, M.G.; Anavigoffer, S.; Fletcher, P.J.; Mechoulam, R.; Pertwee, R.G.; Parker, L.A. Cannabidiol, a non-psychotropic component of cannabis, attenuates vomiting and nausea-like behaviour via indirect agonism of 5-HT1A somatodendritic autoreceptors in the dorsal raphe nucleus. Br. J. Pharmacol. 2012, 165, 2620-2634. [CrossRef]

71. Bolognini, D.; Rock, E.M.; Cluny, N.L.; Cascio, M.G.; Limebeer, C.L.; Duncan, M.; Stott, C.G.; Javid, F.A.; Parker, L.A.; Pertwee, R.G. Cannabidiolic acid prevents vomiting in Suncus murinus and nausea-induced behaviour in rats by enhancing 5-HT1A receptor activation. Br. J. Pharmacol. 2013, 168, 1456-1470. [CrossRef] [PubMed]

72. Anderson, L.L.; Low, I.K.; Banister, S.D.; McGregor, I.S.; Arnold, J.C. Pharmacokinetics of Phytocannabinoid Acids and Anticonvulsant Effect of Cannabidiolic Acid in a Mouse Model of Dravet Syndrome. J. Nat. Prod. 2019, 82, 3047-3055. [CrossRef] [PubMed]

73. Lehrke, M.; Lazar, M.A. The many faces of PPARgamma. Cell 2005, 123, 993-999. [CrossRef] [PubMed]

74. Global, regional, and national life expectancy, all-cause mortality, and cause-specific mortality for 249 causes of death, 1980-2015: A systematic analysis for the Global Burden of Disease Study 2015. Lancet 2016, 388, 1459-1544. [CrossRef]

75. Sciacovelli, M.; Schmidt, C.; Maher, E.R.; Frezza, C. Metabolic Drivers in Hereditary Cancer Syndromes. Annu. Rev. Cancer Biol. 2020, 4, 77-97. [CrossRef]

76. Shekhar, M.P. Drug resistance: Challenges to effective therapy. Curr. Cancer Drug Targets 2011, 11, 613-623. [CrossRef]

77. Li, J.W.H.; Vederas, J.C. Drug Discovery and Natural Products: End of an Era or an Endless Frontier? Science 2009, 325, 161-165. [CrossRef]

78. Newman, D.J.; Cragg, G.M. Natural Products As Sources of New Drugs over the 30 Years from 1981 to 2010. J. Nat. Prod. 2012, 75, 311-335. [CrossRef]

79. Ricote, M.; Glass, C.K. PPARs and molecular mechanisms of transrepression. Biochim. Biophys. Acta (BBA) Mol. Cell Biol. Lipids 2007, 1771, 926-935. [CrossRef]

80. Pascual, G.; Fong, A.L.; Ogawa, S.; Gamliel, A.; Li, A.C.; Perissi, V.; Rose, D.W.; Willson, T.M.; Rosenfeld, M.G.; Glass, C.K. A SUMOylation-dependent pathway mediates transrepression of inflammatory response genes by PPAR-gamma. Nature 2005, 437, 759-763. [CrossRef]

81. Hou, Y.; Moreau, F.; Chadee, K. PPAR $\gamma$ is an E3 ligase that induces the degradation of NFkB/p65. Nat. Commun. 2012, 3, 1300. [CrossRef] [PubMed]

82. Zhou, C.C.; Du, W.; Wen, Z.; Li, J.Y.; Zhang, P. Effects of natural plant ginkgolic acids on the apoptosis of human Hep-2 cancer cells. Sichuan Da Xue Xue Bao. Yi Xue Ban (J. Sichuan Univ. Med. Sci. Ed.) 2009, 40, 459-461.

83. Gerstmeier, J.; Seegers, J.; Witt, F.; Waltenberger, B.; Temml, V.; Rollinger, J.; Stuppneret, H.; Koeberle, A.; Schuster, D.; Werz, O. Ginkgolic Acid is a Multi-Target Inhibitor of Key Enzymes in Pro-Inflammatory Lipid Mediator Biosynthesis. Front. Pharmacol. 2019, 10, 797. [CrossRef] [PubMed]

84. Hua, Z.; Wu, C.; Fan, G.; Tang, Z.; Cao, F. The antibacterial activity and mechanism of ginkgolic acid C15:1. BMC Biotechnol. 2017, 17, 1-12. [CrossRef] [PubMed]

85. Hong, C.; Firestone, G.L.; Bjeldanes, L.F. Bcl-2 family-mediated apoptotic effects of 3,3'-diindolylmethane (DIM) in human breast cancer cells. Biochem. Pharmacol. 2002, 63, 1085-1097. [CrossRef]

86. Wesche-Soldato, D.E.; Swan, R.Z.; Chung, C.S.; Ayala, A. The apoptotic pathway as a therapeutic target in sepsis. Curr. Drug Targets 2007, 8, 493-500. [CrossRef]

87. Mackey, T.J.; Borkowski, A.; Amin, P.; Jacobs, S.C.; Kyprianou, N. bcl-2/bax ratio as a predictive marker for therapeutic response to radiotherapy in patients with prostate cancer. Urology 1998, 52, 1085-1090. [CrossRef]

88. Raisova, M.; Hossini, A.M.; Eberle, J.; Riebeling, C.; Orfanos, C.E.; Geilen, C.C.; Wieder, T.; Sturm, I.; Daniel, P.T. The Bax/Bcl-2 Ratio Determines the Susceptibility of Human Melanoma Cells to CD95/Fas-Mediated Apoptosis. J. Investig. Dermatol. 2001, 117, 333-340. [CrossRef]

89. Lohmann, C.M.; League, A.A.; Clark, W.S.; Lawson, D.; Derose, P.B.; Cohen, C. Bcl-2: Bax and Bcl-2: $\mathrm{Bcl}-\mathrm{x}$ ratios by image cytometric quantitation of immunohistochemical expression in ovarian carcinoma: Correlation with prognosis. Cytometry 2000, 42, 61-66. [CrossRef]

90. Catlett-Falcone, R.; Landowski, T.H.; Oshiro, M.M.; Turkson, J.; Levitzki, A.; Savino, R.; Ciliberto, G.; Moscinski, L.; Fernández-Luna, J.L.; Nuñez, G.; et al. Constitutive Activation of Stat3 Signaling Confers Resistance to Apoptosis in Human U266 Myeloma Cells. Immunology 1999, 10, 105-115. [CrossRef] 
91. Bharti, A.C.; Donato, N.; Aggarwal, B.B. Curcumin (Diferuloylmethane) Inhibits Constitutive and IL-6-Inducible STAT3 Phosphorylation in Human Multiple Myeloma Cells. J. Immunol. 2003, 171, 3863-3871. [CrossRef]

92. Wang, X.; Crowe, P.J.; Goldstein, D.; Yang, J.L. STAT3 inhibition, a novel approach to enhancing targeted therapy in human cancers (review). Int. J. Oncol. 2012, 41, 1181-1191. [CrossRef]

93. Heinrich, P.C.; Behrmann, I.; Haan, S.; Hermanns, H.M.; Müller-Newen, G.; Schaper, F. Principles of interleukin (IL)-6-type cytokine signalling and its regulation. Biochem. J. 2003, 374, 1-20. [CrossRef] [PubMed]

94. Hodge, D.R.; Hurt, E.M.; Farrar, W.L. The role of IL-6 and STAT3 in inflammation and cancer. Eur. J. Cancer 2005, 41, 2502-2512. [CrossRef] [PubMed]

95. Sun, S.; Steinberg, B.M. PTEN is a negative regulator of STAT3 activation in human papillomavirus-infected cells. J. Gen. Virol. 2002, 83, 1651-1658. [CrossRef]

96. Han, Y.; Amin, H.M.; Franko, B.; Frantz, C.; Shi, X.; Lai, R. Loss of SHP1 enhances JAK3/STAT3 signaling and decreases proteosome degradation of JAK3 and NPM-ALK in ALK+ anaplastic large-cell lymphoma. Blood 2006, 108, 2796-2803. [CrossRef] [PubMed]

97. Dorval, V.; Fraser, P.E. SUMO on the road to neurodegeneration. Biochim. Biophys. Acta (BBA) Bioenerg. 2007, 1773, 694-706. [CrossRef] [PubMed]

98. Thompson, P.M.; Hayashi, K.M.; de Zubicaray, G.; Janke, A.L.; Rose, S.E.; Semple, J.; Herman, D.; Hong, M.S.; Dittmer, S.S.; Doddrell, D.M.; et al. Dynamics of gray matter loss in Alzheimer's disease. J. Neurosci. 2003, 23, 994-1005. [CrossRef] [PubMed]

99. Arendt, T. Synaptic degeneration in Alzheimer's disease. Acta Neuropathol. 2009, 118, 167-179. [CrossRef] [PubMed]

100. Deeks, S.G.; Smith, M.; Holodniy, M.; O Kahn, J. HIV-1 protease inhibitors. A review for clinicians. JAMA 1997, 277, 145-153. [CrossRef] [PubMed]

101. Formato, M.; Crescente, G.; Scognamiglio, M.; Fiorentino, A.; Pecoraro, M.T.; Piccolella, S.; Catauro, M.; Pacifico, S. (-)-Cannabidiolic Acid, a Still Overlooked Bioactive Compound: An Introductory Review and Preliminary Research. Molecules 2020, 25, 2638. [CrossRef] [PubMed]

102. Klein, T.W.; Lane, B.; Newton, C.A.; Friedman, H. The cannabinoid system and cytokine network. Proc. Soc. Exp. Biol. Med. 2000, 225, 1-8. [CrossRef] [PubMed]

103. Bidaut-Russell, M.; DeVane, W.A.; Howlett, A.C. Cannabinoid Receptors and Modulation of Cyclic AMP Accumulation in the Rat Brain. J. Neurochem. 1990, 55, 21-26. [CrossRef] [PubMed]

104. Herring, A.C.; Kaminski, N.E. Cannabinol-mediated inhibition of nuclear factor-kappaB, cAMP response element-binding protein, and interleukin-2 secretion by activated thymocytes. J. Pharmacol. Exp. Ther. 1999, 291, 1156-1163.

105. Bonhaus, D.W.; Chang, L.K.; Kwan, J.; Martin, G.R. Dual activation and inhibition of adenylyl cyclase by cannabinoid receptor agonists: Evidence for agonist-specific trafficking of intracellular responses. J. Pharmacol. Exp. Ther. 1998, 287, 884-888. [PubMed]

106. Klein, T.W.; Newton, C.A.; Friedman, H. Cannabinoids and the immune system. Pain Res. Manag. 2001, 6, 95-101. [CrossRef] [PubMed]

107. Grotenhermen, F. Pharmacokinetics and Pharmacodynamics of Cannabinoids. Clin. Pharmacokinet. 2003, 42, 327-360. [CrossRef]

108. Wiley, J.L.; Martin, B.R. Cannabinoid pharmacology: Implications for additional cannabinoid receptor subtypes. Chem. Phys. Lipids 2002, 121, 57-63. [CrossRef]

109. Stone, N.L.; Murphy, A.J.; England, T.J.; O'Sullivan, S.E. A systematic review of minor phytocannabinoids with promising neuroprotective potential. Br. J. Pharmacol. 2020, 177, 4330-4352. [CrossRef] [PubMed]

110. Ríos, J.L.; Francini, F.; Schinella, G.R. Natural Products for the Treatment of Type 2 Diabetes Mellitus. Planta Med. 2015, 81, 975-994. [CrossRef] [PubMed]

111. Pauli, C.S.; Conroy, M.; Heuvel, B.D.V.; Park, S.H. Cannabidiol Drugs Clinical Trial Outcomes and Adverse Effects. Front. Pharmacol. 2020, 11, 63. [CrossRef] [PubMed] 
112. Butler, M.; Robertson, A.A.B.; Cooper, M.A. Natural product and natural product derived drugs in clinical trials. Nat. Prod. Rep. 2014, 31, 1612-1661. [CrossRef] [PubMed]

Publisher's Note: MDPI stays neutral with regard to jurisdictional claims in published maps and institutional affiliations.

(C) 2020 by the authors. Licensee MDPI, Basel, Switzerland. This article is an open access article distributed under the terms and conditions of the Creative Commons Attribution (CC BY) license (http://creativecommons.org/licenses/by/4.0/). 